\title{
Assessment of the usefulness of selected media used in the rooting process of lavender cotton shoot cuttings
}

\author{
Stanistawa Szczepaniak, Zdzistaw Guzikowski, Monika Henschke* \\ Department of Ornamental Plants \\ Poznań University of Life Sciences \\ Dąbrowskiego 159, 60-594 Poznań, Poland
}

\begin{abstract}
Lavender cotton (Santolina chamaecyparissus L.) shoot cuttings, obtained from two-year-old mother plants, were rooted in five different media under an unheated foil tunnel. Two ready-made and widely recommended media were used: Hartmann peat substrate and Ceres peat-coconut substrate, as well as three prepared mixtures: high peat + mineral soil, high peat + perlite and high peat + sand. The influence of medium type on the number of rooted cuttings and the quality of the root system was assessed for two cultivation times during a three-year study after eight weeks from the date of cutting. As far as the ready-made rooting substrates are concerned, Ceres peat-coconut substrate turned out to be better when compared with the Hartmann substrate. The number of high quality rooted cuttings was larger when media containing high peat mixed with either mineral soil or sand were used in comparison with the mixture of high peat and perlite.
\end{abstract}

Key words: cultivation times, peat-coconut substrate, quality rooted cuttings, rooting substrates, Santolina chamaecyparissus

\section{INTRODUCTION}

One of the important factors influencing the effects of rooting process is selection of the proper medium. According to Neitzel et al. (1997), sand, peat mixed with sand, mineral soil, compost soil, and also (as additives) vermiculite and gravel are used as media in the process of rooting perennials. In the majority of German perennial-breeding nurseries out of 40 questioned, mixtures of peat and sand were used as a substrate. According to Feßler and Köhlein (1997), mixtures of peat and sand in the proportions 2:1 or 1:3 are usually used. The authors stress that quartz sand with a grain size of 0.5-2 mm is the best. Szczepaniak (1998) claims that the addition of sand to peat improves soil physical properties and its permeability, but simultaneously, it increases its volumetric density and also causes the scattering of medium lumps during the replanting process which, in turn, results in the tearing of delicate roots. However, adding coarse-grained components to peat, such as perlite, gravel, small-grained expanded clay, composted bark or granulated mineral wool, prevents its settling and shrinking, which results in a gradual diminishing of air volume (Salvador and Minami 2008). According to Westervelt (2003), perlite can be used in medium as a substitute for sand increasing aeration and drainage. However, Anicua-Sanchez et al. (2008) point out that the level of available water retention is lower in perlite when compared to media made of coconut fibre or high peat. Nowadays, commercial substrates,

\footnotetext{
*Corresponding author.

Tel.: +48 509553 236;

e-mail: mohen@up.poznan.pl (M. Henschke).
} 
produced on a large scale and consisting of uniform, strictly controlled components as far as quality is concerned and fulfilling European Union regulations concerning peat and peat-based media are available more and more often (Blok and Verhagen 2009). They determine the optimal physical properties of media used for the rooting process of ornamental plants cuttings. According to the authors there are as follows: volumetric density 60-250 $\mathrm{mg} \mathrm{m}^{-3}$, organic matter 15-40\% (v:v), shrinkage $35-40 \%$ (v:v), general porosity $85-95 \%$ (v:v), water retention $70-80 \%$ (v:v), air capacity $15-20 \%$ (v:v), available water $30-40 \%$. The correct physical characteristics of growing media ensure the retention of good moisture after irrigation and keep the turgor of cuttings and ensure that oxygen supports vascular cambium activity enhancing the formation of calluses and roots. Apart from physical properties the substrate used for the rooting process of cuttings should be above all sterile and poor in nutrients (Kukkonen and Vestberg 2009). The selection of the medium used for the rooting process of cuttings is dependent upon the species of the plant and its further cultivation.

Recently perennials with ornamental leaves, such as lavender cotton, have been becoming more and more popular. According to Jelitto et al. (2002), this perennial is usually used for low, formed or natural hedgerows which, due to their winter hardiness and aromatic, grey and green, sparkling leaves add variety to plant arrangements. There is a lack of information about the influence of the medium on the rooting of lavender cotton stem cuttings.

Vegetative propagation guarantees obtaining plants characterized by balanced growth. Therefore, the study was commenced in order to determine which medium ensures the best effects for the rooting process of lavender cotton shoot cuttings.

\section{MATERIAL AND METHODS}

The objective of the conducted study was the evaluation of commercial rooting media available on the market and also self-made mixtures of media containing high peat for the rooting of lavender cotton (Santolina chamaecyparissus L.) 'Nana'. The study was conducted in three successive years: 2006, 2007 and 2008, at two fixed terms: 16 August and 16 September. Shoot cuttings obtained from the apical part of the mother plant were $5 \mathrm{~cm}$ long. Leaves from the bottom part of the shoot cutting, that is the part placed in the ground $(1-1.5 \mathrm{~cm})$, were removed. In the experiment, five types of media were used: I - Hartmann commercial peat-based substrates dedicated for shoot cutting rooting; II - Ceres peat-coconut substrate; III - high peat + mineral soil $(1: 1 ; \mathrm{v}: \mathrm{v})$; IV - high peat + perlite $(1: 1$; $\mathrm{v}: \mathrm{v}) ; \mathrm{V}-$ high peat + sand $(1: 1 ; \mathrm{v}: \mathrm{v})$. The nutrient content of the high peat from Pasłęk that was used to prepare the media (in $\mathrm{mg} \mathrm{dm}^{-3}$ ) was as follows: $\mathrm{N}-\mathrm{NH}_{4}-21, \mathrm{~N}^{-\mathrm{NO}_{3}}-22, \mathrm{P}-50, \mathrm{~K}-40, \mathrm{Mg}-$ $10, \mathrm{Ca} 300, \mathrm{pH}$ in $\mathrm{H}_{2} \mathrm{O}-4.0$. High peat was deacidified with the use of $4 \mathrm{~g} \mathrm{CaCO}_{3} \mathrm{dm}^{-3}$ so that the $\mathrm{pH}$ was about 6.0. Then, the medium mixtures were prepared by means of volumetric mixing of high peat with sand, perlite or mineral soil taken from the arable layer. The self-prepared growing was amended with $0.5 \mathrm{~g} \mathrm{dm}^{-3}$ of complete fertilizer Azofoska ( $\mathrm{N}-13.6, \mathrm{P}-2.8, \mathrm{~K}-15.0, \mathrm{Ca}-9.0$, $\mathrm{Mg}-2.7$ and microelements). Commercial rooting media were enriched in fertilizers by the producers. According to the producer's information, the Hartmann substrate contained $0.5 \mathrm{~g} \mathrm{dm}^{-3}$ of PG Mix fertilizer $\left(\mathrm{N}-14, \mathrm{P}_{2} \mathrm{O}_{5}-16, \mathrm{~K}_{2} \mathrm{O}-18\right)$ and Ceres substrate contained $0.5 \mathrm{~g} \mathrm{dm}^{-3}$ of Hydrocote $(\mathrm{N}-13, \mathrm{P}-13, \mathrm{~K}-13, \mathrm{Ca}-13, \mathrm{Mg}-2)$. Salt concentration in the media used was similar $1.0 \mathrm{~g} \mathrm{NaCl} \mathrm{dm}^{-3}$. The plant cuttings, after being treated with rooting hormones (commercially available rooting substance "B" for green cuttings), were placed in the rooting media. The beds were in an unheated tunnel filled with a $10 \mathrm{~cm}$ layer of gravel and a $10 \mathrm{~cm}$ layer of the tested medium. Low tunnels made of white nonwoven ground cover type P-17 were installed above the beds with cuttings for the maintenance of high air humidity (80-90\%). Hand spray was used when it was necessary. The average temperature depended on the year of rooting and was: $16.4-17.7^{\circ} \mathrm{C}$ in August, $13.6-17.0^{\circ} \mathrm{C}$ in September, $8.3-11.2^{\circ} \mathrm{C}$ in October, and $2.6-6.7^{\circ} \mathrm{C}$ in November. After eight weeks, the number of rooted cuttings, the number of adventitious roots longer than $2 \mathrm{~cm}$, the length of the longest root in $\mathrm{cm}$ and the width of the root system in $\mathrm{cm}$ were determined. The experiment was conducted as a random process. Each treatment consisted of four replications with five cuttings each, which resulted in 20 cuttings. The obtained results were analysed statistically by means of two-variance analysis. The studies evaluated whether the term of cuttings taken had an influence apart from the medium used on the number of rooted cuttings (Tab. 1) and whether the year of studies influenced the quality of rooted cuttings (Tabs 2 and 3). The means were grouped with the use of the Duncan test at the significance level of $p=0.05$. In order to assess 
the number of rooted cuttings, the obtained values were expressed as percentages and the results were again statistically analysed by means of an analysis of variance, transforming percentage values into angular ones according to Bliss tables.

\section{RESULTS AND DISCUSSION}

The three-year experiment conducted on 16 August and 16 September in successive years proved that the medium type had a significant effect on the rooting process of lavender cotton. The average number of rooted cuttings was the largest for the Ceres peat-coconut substrate (93.3\%); a similar number was obtained in the mixture of peat with sand (1:1) (92.5\%) and also in the mixture of peat with mineral soil (91.7\%) (Tab. 1). The percentage of rooted cuttings was significantly lower $(67.5 \%$ and $61.7 \%$ ) in the commercial Hartmann rooting medium and also in the mixture of peat with perlite (1:1). According to Westervelt (2003), a coconut medium can be a substitute for a peat medium. But properties of coconut media such as longer durability and lower cation exchange capacity correspond to good rooting of lavender cotton in our own research. In addition, Sangaré et al. (2013) claim that a nursery medium consisting of aged bark and Canadian peat (1:1 v:v) with an addition of $30 \%$ coconut has a better relative gas diffusivity about $47 \%$. Peats from the Nordic and the Baltic countries shrink under the influence of lime at a dose above $4 \mathrm{~g} \mathrm{~m}^{-3}$ (Maher and Prasad 2004). In our own research the number of rooted cuttings in the commercial Hartmann medium was lower by $25 \%$ when compared with the number of rooted cuttings in the Ceres medium. The peat-coconut Ceres medium contains slow-release Hydrocote fertilizer while the peat substrate Hartmann, and also other media used in the experiment, contained mineral fertilizer. However, the fertilizer type used in the media might not influence the rooting process because, as proved by Rowe and Cregg (2002) in an experiment with rooting three perennial species, two types of Nutricote fertilizer in dosages equal or higher than $0.77 \mathrm{~g} \mathrm{dm}^{-3} \mathrm{~N}$ did not have a favourable effect on the rooting process. In the medium consisting of peat and perlite, only $61.7 \%$ cuttings rooted on average. According to Neitzel et al. (1997), in German perennial-breeding nurseries perlite is not used, although this medium is generally recommended for rooting ornamental plant shoot cuttings. Kreen et al. (2002) obtained more rooted non-woody shoot cuttings of five cultivars of clematis in pure perlite $(71 \%)$ than in the mixture of peat and perlite (36\%). Nowak (2004) also noted worse results of rooting in the mixture of peat with perlite than in the peat-coconut substrate while rooting New Guinea Impatiens, as did Szczepaniak (1998) during the rooting process of Peruvian lily in a peat medium. However, Evans and Stamps (1996), giving the basic physical properties of gardening media, assessed that a mixture of peat and perlite in a ratio of 80:20 has a higher water capacity than in a ratio of 20:80 (964\% wgt; $618 \% \mathrm{wgt})$ and lower air-filled pore space ( $11.6 \% \mathrm{vol} ; 13.3 \% \mathrm{vol})$. On the other hand, Giroux et al. (1999) proved that the $\mathrm{pH}$ value of the medium could have a significant influence on the rooting of softwood stem cuttings. In a mixture of peat and perlite, with the increasing participation of perlite the $\mathrm{pH}$ value increased, which could have a negative effect on the rooting of cuttings. However, Lee et al. (2009) claim that in the rooting process of Hydrangea serrata for. acuminata the least rooted cuttings were obtained in the mixture of peat, perlite and vermiculite (v:v:v 1:1:1) and the worst growth of roots was recorded in a coir dust:perlite medium (v:v 1:1). In our own research, $100 \%$ of cuttings rooted in the medium consisting of peat and mineral soil at the second rooting time (16 September). Fewer rooted cuttings

Table 1. Influence of medium on the number of rooted lavender cotton cuttings propagated on 16 August and 16 September $(\%)$ (mean from three years)

\begin{tabular}{lccc}
\hline \multirow{2}{*}{ Rooting medium } & \multicolumn{2}{c}{ Rooting time } & Mean \\
\cline { 2 - 3 } & 16 August & 16 September & $67.5 \mathrm{~A}$ \\
\hline I. Peat substrate - Hartmann & $71.7 \mathrm{abc} *$ & $63.3 \mathrm{ab}$ & $93.3 \mathrm{~B}$ \\
II. Peat-coconut substrate - Ceres & $91.7 \mathrm{bcde}$ & $95.0 \mathrm{cde}$ & $91.7 \mathrm{~B}$ \\
III. High peat + mineral soil (1:1) & $83.3 \mathrm{bcd}$ & $100.0 \mathrm{e}$ & $61.7 \mathrm{~A}$ \\
IV. High peat + perlite (1:1) & $43.3 \mathrm{a}$ & $80.0 \mathrm{bcd}$ & $92.5 \mathrm{~B}$ \\
V. High peat + sand (1:1) & $86.7 \mathrm{bcd}$ & $98.0 \mathrm{de}$ & $87.3 \mathrm{~B}$ \\
Mean & $75.3 \mathrm{~A}$ & 8 \\
\hline
\end{tabular}

*Means that did not differ significantly are marked with the same letters at the significance level $p=0.05$ 
were obtained in the mixture of peat and sand $(88.3 \%)$ and in the Ceres medium (95\%); however, the differences were not statistically significant. However, the addition of sand to peat (15\%) can have a negative effect, for example the reduction of fresh weight of the whole plant and branching (Strojny and Nowak 2004). At the second rooting term, in autumn, the number of rooted cuttings in the mixture of peat and perlite was significantly higher when compared with the late summer time. Similarly, Anicua-Sanchez et al. (2008) observed better rooting in media with perlite in autumn. Piskornik (2002) proved that the percentage of rooted Christmas rose cuttings in the medium with perlite kept rising systematically at later rooting times: $42 \%$ in August, $65 \%$ in September and $76 \%$ in October. The reason for this fact may be that higher temperatures in the early terms of rooting dry out substrates, especially mixtures with perlite, or longer days and better vegetation during the summer months, which can affect the quality of the mother plants.

The quality of rooted cuttings assessed in our own research on the basis of formed roots, their length and the width of the root system, was also dependant on the medium used. At the first rooting term (16 August), all of the examined qualitative features exhibited the highest values in the medium consisting of high peat mixed with mineral soil (Tab. 2), while at the second rooting time (16 September) the highest values were found in the medium consisting of peat and sand (Tab. 3). According to Piskornik (2002), the advantage of using a mixture of mineral soil and peat in the rooting process conducted in pots is the fact that immediately after rooting the plants do not need to be replanted into a more substantial medium, as is necessary in the case of perlite. In our own research, the width of the lavender cotton root system (in the case of the rooting process which was commenced on 16 August) in the Ceres medium $(4.4 \mathrm{~cm})$, prepared on the basis of coconut fibre, did not differ significantly from the width obtained in the medium consisting of peat and mineral soil $(4.5 \mathrm{~cm})$. At the second examination term, both the number of roots (9.1) and the length of the longest $\operatorname{root}(7.8 \mathrm{~cm})$ in the Ceres medium were similar to the values obtained in the medium consisting of peat and sand $(9.9 ; 8.2 \mathrm{~cm})$.

While comparing commercial rooting media used in the rooting process of lavender cotton, the Ceres peat-coconut substrate proved to be better than the Hartmann peat substrate. The favourable effect of coconut fibres on the rooting process of osteosperma was recorded by Nowak (2004), and could be associated with the specific physical

Table 2. Influence of rooting medium on the number of rooted lavender cotton cuttings propagated on 16 August in three subsequent years of the experiment

\begin{tabular}{|c|c|c|c|c|c|c|}
\hline \multirow[b]{2}{*}{ Year } & \multicolumn{5}{|c|}{ Medium } & \multirow[b]{2}{*}{ Mean } \\
\hline & $\begin{array}{l}\text { Peat substrate } \\
\text { - Hartmann }\end{array}$ & $\begin{array}{l}\text { Peat-coconut } \\
\text { substrate } \\
\text { - Ceres }\end{array}$ & $\begin{array}{l}\text { High peat } \\
+ \text { mineral soil } \\
\quad(1: 1)\end{array}$ & $\begin{aligned} & \text { High peat } \\
+ & \text { perlite }(1: 1)\end{aligned}$ & $\begin{array}{l}\text { High peat } \\
+ \text { sand }(1: 1)\end{array}$ & \\
\hline \multicolumn{7}{|c|}{ Number of roots } \\
\hline 2006 & $2.8 \mathrm{~b}^{*}$ & $5.1 \mathrm{~cd}$ & $5.3 \mathrm{~cd}$ & $0.6 \mathrm{a}$ & $3.9 \mathrm{bc}$ & $3.5 \mathrm{~A}$ \\
\hline 2007 & $3.8 \mathrm{~cd}$ & $6.1 \mathrm{~d}$ & $6.4 \mathrm{de}$ & $1.3 \mathrm{a}$ & $4.0 \mathrm{bc}$ & $4.3 \mathrm{~B}$ \\
\hline 2008 & $4.8 \mathrm{~cd}$ & $3.8 \mathrm{bc}$ & $5.9 \mathrm{~d}$ & $1.3 \mathrm{a}$ & $7.8 \mathrm{e}$ & $4.7 \mathrm{~B}$ \\
\hline Mean & $3.8 \mathrm{~B}$ & $5.0 \mathrm{C}$ & 5.9 D & $1.1 \mathrm{~A}$ & $5.2 \mathrm{CD}$ & \\
\hline \multicolumn{7}{|c|}{ Length of the longest root $(\mathrm{cm})$} \\
\hline 2006 & $3.3 \mathrm{c}$ & $5.6 \mathrm{def}$ & 5.7 def & $0.9 \mathrm{a}$ & $4.8 \mathrm{~d}$ & $4.1 \mathrm{~A}$ \\
\hline 2007 & $5.3 \mathrm{def}$ & $6.0 \mathrm{ef}$ & $6.4 \mathrm{fg}$ & $1.5 \mathrm{ab}$ & $3.3 \mathrm{c}$ & $4.5 \mathrm{~A}$ \\
\hline 2008 & $5.6 \mathrm{def}$ & $5.0 \mathrm{de}$ & $7.3 \mathrm{gh}$ & $2.2 \mathrm{~b}$ & $8.1 \mathrm{~h}$ & $5.6 \mathrm{~B}$ \\
\hline Mean & $4.7 \mathrm{~B}$ & $5.5 \mathrm{C}$ & $6.5 \mathrm{D}$ & $1.6 \mathrm{~A}$ & $5.4 \mathrm{C}$ & \\
\hline \multicolumn{7}{|c|}{ Width of the root system $(\mathrm{cm})$} \\
\hline 2006 & $2.0 \mathrm{bc}$ & 4.2 ef & $4.3 \mathrm{ef}$ & $1.1 \mathrm{a}$ & $2.7 \mathrm{~cd}$ & $2.8 \mathrm{~A}$ \\
\hline 2007 & $4.7 \mathrm{fg}$ & $5.3 \mathrm{gh}$ & $5.7 \mathrm{~h}$ & $1.3 \mathrm{ab}$ & $2.7 \mathrm{~cd}$ & $3.9 \mathrm{C}$ \\
\hline 2008 & $3.4 \mathrm{de}$ & $3.7 \mathrm{e}$ & $3.6 \mathrm{de}$ & $1.3 \mathrm{ab}$ & $4.9 \mathrm{fgh}$ & $3.4 \mathrm{~B}$ \\
\hline Mean & $3.4 \mathrm{~B}$ & $4.4 \mathrm{C}$ & $4.5 \mathrm{C}$ & $1.2 \mathrm{~A}$ & $3.4 \mathrm{~B}$ & \\
\hline
\end{tabular}

*Explanations: see Table 1 
Table 3. Influence of medium on the number of rooted lavender cotton cuttings propagated on 16 September in three subsequent years of the experiment

\begin{tabular}{|c|c|c|c|c|c|c|}
\hline \multirow[b]{2}{*}{ Year } & \multicolumn{5}{|c|}{ Medium } & \multirow[b]{2}{*}{ Mean } \\
\hline & $\begin{array}{l}\text { Peat substrate } \\
\text { - Hartmann }\end{array}$ & $\begin{array}{l}\text { Peat-coconut } \\
\text { substrate } \\
\text { - Ceres }\end{array}$ & $\begin{aligned} & \text { High peat } \\
&+ \text { mineral soil } \\
& \quad(1: 1)\end{aligned}$ & $\begin{aligned} & \text { High peat } \\
+ & \text { perlite }(1: 1)\end{aligned}$ & $\begin{array}{l}\text { High peat } \\
+ \text { sand }(1: 1)\end{array}$ & \\
\hline \multicolumn{7}{|c|}{ Number of roots } \\
\hline 2006 & $7.0 c^{*}$ & $6.7 \mathrm{c}$ & $7.0 \mathrm{c}$ & $4.2 \mathrm{~b}$ & $10.6 \mathrm{de}$ & $7.1 \mathrm{~A}$ \\
\hline 2007 & $3.9 \mathrm{~b}$ & 10.6 de & 9.1 cde & $0.2 \mathrm{a}$ & $7.3 \mathrm{c}$ & $6.2 \mathrm{~A}$ \\
\hline 2008 & $8.4 \mathrm{~cd}$ & $10.1 \mathrm{de}$ & $10.2 \mathrm{de}$ & $2.0 \mathrm{ab}$ & $11.9 \mathrm{e}$ & $8.5 \mathrm{~B}$ \\
\hline Mean & $6.4 \mathrm{~B}$ & $9.1 \mathrm{C}$ & $8.8 \mathrm{C}$ & $2.1 \mathrm{~A}$ & $9.9 \mathrm{C}$ & \\
\hline \multicolumn{7}{|c|}{ Length of the longest root $(\mathrm{cm})$} \\
\hline 2006 & $5.8 \mathrm{~d}$ & $7.1 \mathrm{de}$ & $6.5 \mathrm{de}$ & $2.5 \mathrm{~b}$ & $6.7 \mathrm{de}$ & $5.7 \mathrm{~B}$ \\
\hline 2007 & $3.7 \mathrm{c}$ & $7.6 \mathrm{ef}$ & $6.7 \mathrm{de}$ & $0.7 \mathrm{a}$ & $6.7 \mathrm{de}$ & $5.1 \mathrm{~A}$ \\
\hline 2008 & $6.7 \mathrm{de}$ & $8.7 \mathrm{fg}$ & $9.3 \mathrm{~g}$ & $2.2 \mathrm{~b}$ & $11.3 \mathrm{~h}$ & 7.6 C \\
\hline Mean & $5.4 \mathrm{~B}$ & $7.8 \mathrm{CD}$ & $7.5 \mathrm{C}$ & $1.8 \mathrm{~A}$ & $8.2 \mathrm{D}$ & \\
\hline \multicolumn{7}{|c|}{ Width of the root system $(\mathrm{cm})$} \\
\hline 2006 & $4.1 \mathrm{de}$ & $3.9 \mathrm{~d}$ & $4.0 \mathrm{~d}$ & $2.1 \mathrm{bc}$ & $5.0 \mathrm{ef}$ & $3.8 \mathrm{~A}$ \\
\hline 2007 & $2.9 \mathrm{c}$ & $7.0 \mathrm{~h}$ & $5.6 \mathrm{fg}$ & $0.7 \mathrm{a}$ & $6.3 \mathrm{gh}$ & $4.5 \mathrm{~B}$ \\
\hline 2008 & $3.8 \mathrm{~d}$ & $5.4 \mathrm{f}$ & $5.6 \mathrm{fg}$ & $1.3 \mathrm{ab}$ & $9.1 \mathrm{i}$ & $5.0 \mathrm{C}$ \\
\hline Mean & $3.6 \mathrm{~B}$ & $5.4 \mathrm{C}$ & $5.1 \mathrm{C}$ & $1.4 \mathrm{~A}$ & $6.8 \mathrm{D}$ & \\
\hline
\end{tabular}

*Explanations: see Table 1

and chemical properties of lignin, which are the major component of coconut fibres. According to the author, plants grown in a mixture of peat:coco coir (v:v 1:1) had a greater fresh and dry weight of roots and length than those grown in a mixture of peat:coco coir (v:v 2:1). According to Smith (1995), the beneficial physical properties of the medium with coconut fibres are due to their slower mineralization when compared with peat, and also due to the fact that coconut fibres do not shrink when the medium gets drier and they are easy to moisturize again. These properties provide high oxygen content in media containing coconut fibres, whereas oxygen scarcity in the medium results in the growth retardation of both roots and the terrestrial part of the plant because of the decrease in photosynthesis intensity and disturbances in the transportation of photosynthesis products and mineral components. According to Lokesha et al. (1988), it is also the chemical properties of coconut fibres that can have a favourable effect on the rooting process due to the presence of phenolic compounds developed in the process of lignin decomposition. At low concentrations, these compounds enhance the process of root growth or together with auxins they have a favourable effect onto the rooting process. In addition, BeckmannCavalcante et al. (2009) proved that the negative effect of peats may not be due to the fact of low $\mathrm{N}$ concentration or low air capacity but from the fact of too low concentration of $\mathrm{Fe}$ available for plants. In our own research, the worst qualitative properties were observed in the cuttings rooted in perlite mixed with peat. The number of formed roots, the length of the longest root and the width of the root system were four times lower than in the other examined media. Before the experiment in question many authors had already mentioned the lower quality of ornamental plant cuttings rooted in a medium consisting of peat mixed with perlite.

\section{CONCLUSIONS}

1. Better effects of rooting lavender cotton shoot cuttings were obtained with the Ceres peatcoconut substrate than with the Hartmann peat substrate.

2. Proper media mixtures containing high peat used in lavender cotton propagation are media consisting of high peat mixed either with mineral soil or with sand.

3. Cuttings rooted on 16 September had better quality than those rooted on 16 August.

\section{FUNDING}

This work was financially supported by the Ministry of Science and Higher Education as part of 
the research to sustain the research potential of the Department of Ornamental Plants at the University of Life Sciences in Poznań.

\section{AUTHOR CONTRIBUTIONS}

S.S. - concept of the study; Z.G., S.S. - field research; Z.G., S.S. - data analyses; S.S., M.H. writing of the manuscript; S.S., M.H. - comments on the manuscript.

\section{CONFLICT OF INTEREST}

Authors declare no conflict of interest.

\section{REFERENCES}

Anicua-Sanchez R., Gutierrez-Castorena M.C., SAnchez-Garcia P., 2008. Physical and micromorphological properties of organic and inorganic materials for preparing growing media. Acta Hort. 779: 557-563.

Beckmann-Cavalcante M.Z., Lopez-Pivetta K.F., Meinken E., Roeber R., 2009. Growth of Chrysanthemum $\times$ grandiflorum in different peats and change of peat properties during cultivation. Acta Hort. 819: 181-184.

Blok C., Verhagen J.B.G.M., 2009. Trends in rooting media in Dutch horticulture during the period 20012005: the new growing media project. Acta Hort. 819: 47-57.

Evans M.R., Stamps R.H., 1996. Growth of bedding plants in sphagnum peat and coir dust-based substrates. J. Environ. Hort. 14(4): 187-190.

Feßler A., KöHLein F., 1997. Kulturpraxis der FreilandSchmuckstauden. Verlag Eugen Ulmer Stuttgart: 266, 323-336.

Giroux G.J., Maynard B.K., Johnson W.A., 1999. Comparison of perlite and peat:perlite rooting media for rooting softwood stem cuttings in a subirrigation system with minimal mist. J. Environ. Hort. 17(3): 147-151.

Jelitto L., Schacht W., Simon H., 2002. Die Freiland Schmuckstauden: Handbuch und Lexikon der Gartenstauden. Verlag Eugen Ulmer Stuttgart: 814816.

Kreen S., Svensson M., Rumpunen K., 2002. Rooting of clematis microshoots and stem cuttings in different substrates. Sci. Hort. 96: 351-357.
Kukkonen S.,Vestberg M., 2009. Nursery growers' experiences of growing media - a Finnish case study. Acta Hort. 819: 273-277.

Lee S.Y., Yoon N.H., Gu J.H., Jeong S.J., Kim K.J., Rhee J.CH., ET AL., 2009. Effect of leaf number and rooting media on adventitious rooting of softwood cuttings in native Hydrangea serrata for. acuminate. Kor. J. Hort. Sci. Technol. 27(2): 199-204.

Lokesha R., Mahishi D.M., Shivashankar G., 1988. Studies of the use of coconut coir dust as a rooting media. Current Res. (Bangalore) 17(12): 157-158.

Maher M.J., Prasad M., 2004. The effect of peat type and lime on growing medium $\mathrm{pH}$ and structure and on growth of Hebe pinquifolia 'Sutherlandii'. Acta Hort. 644: 131-137.

Neitzel M., Bott P., Herbst W., Spethmann W., 1997. Sind Wuchsstoffe bei Stauden zu rechtfertigen? Taspo Gartenbaumagazin 6(8): 36-37.

NowaK J., 2004. The effects of rooting media, $\mathrm{CO}_{2}$ enrichment, P-nutrition and mycorrhizal inoculation on rooting and growth of Osteospermum. Acta. Hort. 644: 589-592.

Piskornik M., 2002. Rozmnażanie ciemiernika białego (Helleborus niger) z sadzonek. Zesz. Probl. Post. Nauk Roln. 483: 187-194.

Rowe D., CRegG B.M., 2002. Effect of incorporating controlled-release fertilizer on adventitious rooting and growth of Artemisia, Gaura and Nepeta. J. Environ. Hort. 20(1): 1-6.

Salvador E.D., Minami K., 2008. Evaluation of different substrates on gloxinia (Sinningia speciosa Lood. Hierin.) growth. Acta Hort. 779: 555-560.

SAngaré M., Nemati M.R., Fortin J.P., 2013. Beneficial effect of coconut fiber and peat on the physical quality of nursery substrates. Acta Hort. 1013: 175180.

Sмiтн CH., 1995. Coir: a viable alternative to peat for potting. The Horticulturist 4(3): 12-25.

Strojny Z., Nowak J.S., 2004. Effect of different growing media on the growth of some bedding plants. Acta Hort. 644: 157-162.

SzCzePAniak S., 1998. Ocena podłoży do ukorzeniania fragmentów kłączy alstremerii. Zesz. Probl. Post. Nauk Roln. 461: 445-455.

Westervelt P.M., 2003. Greenhouse production of Rosmarinus officinalis L. Master Thesis, Virginia Polytechnic Institute and State University, Blacksburg, Virginia, USA, 51 p.

Received June 15, 2016; accepted November 14, 2016 